УДК 617(7.02)=16(050)(100)"2"-05

DOI 10.11603/2414-4533.2019.3.10546

(с). Є. ПОДПРЯТОВ, І. О. БєЛОУСОВ, С. С. ПОДПРЯТОВ, В. В. ІВАХА, В. П. КОРЧАК

Київська міська клінічна лікарня № 1

\title{
Хірургічне лікування діастазу прямих м'язів живота та гриж на його тлі
}

\begin{abstract}
Мета роботи: оцінити ефективність різних способів хірургічного лікування діастазу прямих м’язів живота (ПМЖ) із позицій досягнення мети оперативного втручання та прийнятності для пацієнта.

Матеріали і методи. Хірургічне втручання виконано 92 пацієнтам, з яких 49 - чоловіки та 43 - жінки віком від 40 до 72 років. Індекс маси тіла пацієнтів становив від 27,2 до 48,6 кг/см².

У 47 пацієнтів на тлі діастазу ПМЖ була післяопераційна грижа живота, у 45 - первинна. Грижа М1 - у 1 пацієнта, М2 - у 11 , M3 - у 42, M4 - у 8, M2+M3+M4 - у 30, W1 - у 3, W2 - y 48, W3 - y 41.

Результати досліджень та їх обговорення. У 5 пацієнтів усунення грижі і діастазу ПМЖ та закриття грижових воріт виконали за способом Ramirez O. M. et al., 1990, доповненим розташуванням поліпропіленової сітки позаду ПМЖ. Хоча мету операції було досягнуто у всіх спостереженнях, однак у післяопераційному періоді ПМЖ повністю, а бокові м’язи черевної стінки майже повністю втратили здатність до скорочення, що суттєво обмежило рухи тулуба пацієнтів.

У 76 пацієнтів зміцнювали передній листок апоневрозу за допомогою розміщення сітки оn lay і за її допомогою зближували ПМЖ. Мобілізацію здійснювали за допомогою технології електрозварювання живих тканин із використанням апаратів ЕК 300-M1 і Патонмед ЕКВ3 300. В усіх спостереженнях ширина діастазу в епігастрії відображала відстань між точками фіксації внутрішніх країв ПМЖ до реберної дуги. При ширині грижових воріт більше 10 см було неможливе зведення внутрішніх країв ПМЖ. У 3 пацієнтів виникла серома, що зумовило висічення сітки. В 11 пацієнтів успішно виконано фіксацію сітки до відсепарованих задніх листків апоневрозу ПМЖ із подальшим їх зшиванням. Виникнення діастазу ПМЖ є наслідком широкого розходження місць фіксації ПМЖ до реберної дуги, яке ми спостерігали у всіх пацієнтів, ймовірність їх змикання відсутня через розходження при кожному скороченні м’язів. В разі виникнення грижі на тлі діастазу краї грижових воріт не мають схильності до зближення.

Мобілізація заднього листка апоневрозу ПМЖ і його зміцнення сіткою дозволяє закрити грижовий дефект шириною до 12 см і є високоефективним при лікуванні грижі на тлі діастазу ПМЖ.

Застосування комбінації ендотрахеального наркозу та епідуральної анестезії з продовженням епідуральної анестезії впродовж 4 - 7 днів після операції забезпечує безбольовий перебіг післяопераційного періоду.
\end{abstract}

Ключові слова: діастаз прямих м’язів живота; грижа; хірургічне лікування.

Постановка проблеми і аналіз останніх досліджень та публікацій. Діастаз прямих м'язів живота (ПМЖ) впливає на загальну якість життя та здоров'я людини через зменшення сили м'язів живота та труднощі з дотриманням належної статури хребта, що супроводжується болем у попереку [1]. Діастаз ПМЖ є важливим чинником рецидиву епігастральної або пупкової грижі після її лікування та виникнення грижі після виконання серединної лапаротомії [2].

Для корекції діастазу ПМЖ запропоновано багато способів оперативного втручання з використанням відкритого та ендоскопічного доступу, різних розташувань грижової сітки без однозначної оцінки переваг. Це свідчить про відсутність чіткого визначення найбільш ефективного способу хірургічного втручання.

Мета роботи: оцінити ефективність різних способів хірургічного лікування діастазу ПМЖ із позицій досягнення мети оперативного втручання та прийнятності для пацієнта.

Матеріали і методи. Хірургічне втручання проведено 92 пацієнтам: 49 чоловікам та 43 жін- кам віком від 40 до 72 років, медіана - 59, міжквартильний розмах - 17 років. Індекс маси тіла пацієнтів становив від 27,2 до 48,6 кг/см², медіана



У 47 пацієнтів на тлі діастазу ПМЖ була післяопераційна грижа живота, у 45 - первинна. Згідно з класифікацією [3] грижа М1 була у 1 пацієнта, M2 - y 11, M3 - у 42, M4 - у 8, M2+M3+M4 - y 30, W1 - y 3, W2 - y 48, W3 - y 41.

У 23 спостереженнях діастаз обмежувався проміжком від мечоподібного відростка до рівня дугоподібної лінії, при цьому діаметр пупкового кільця не перевищував 1 см, в інших спостереженнях діастаз ПМЖ по всій відстані від мечоподібного відростка до лобка.

Результати досліджень та їх обговорення. При виконанні операції ширина діастазу ПМЖ становила від 4 до 12 см. У всіх спостереженнях передня стінка апоневрозу ПМЖ була дистрофічно змінена, з них в 48 настільки, що через стоншений апоневроз видно було волокна м'язів. Такий стан апоневрозу унеможливлював використання його в якості опорного матеріалу для пластики. 
У 5 пацієнтів (1-ша група) 3 шириною діастазу 10 см та грижовими воротами M2+M3+M4, W3 метою операції було усунення грижі і діастазу ПМЖ та закриття грижових воріт способом розшарування черевної стінки за Ramirez O. M., Ruas E., Dellon A. L., доповненим розташуванням поліпропіленової сітки позаду ПМЖ.

Хоча мета хірургічного втручання була досягнута у всіх спостереженнях, однак в післяопераційному періоді ПМЖ повністю, а бокові м'язи черевної стінки майже повністю, втратили здатність до скорочення, що суттєво обмежило рухи тулуба пацієнтів.

У 76 пацієнтів (2-га група) з шириною діастазу 8 - 12 см та грижовими воротами M2+M3+M4, W3 (25 спостережень), M3, W3 (11 спостережень), M3, W2 (40 спостережень) для усунення діастазу закриття грижових воріт застосували зміцнення переднього листка апоневрозу за допомогою розміщення сітки on lay і зближення за її допомогою ПМЖ. Умовою виконання такого втручання була мобілізація підшкірної основи від поверхні переднього листка апоневрозу ПМЖ.

Мобілізацію здійснювали за допомогою технології електрозварювання живих тканин із використанням апаратів ЕК 300-M1 і Патонмед ЕКВ3 300. Завдяки цьому загальна тривалість мобілізації складала $14-20$ хвилин, а тканини зберігали природний стан. При цьому була можлива візуалізація місць фіксації внутрішніх країв ПМЖ до реберної дуги. В усіх спостереженнях ширина діастазу в епігастрії відображала відстань між точками фіксації внутрішніх країв ПМЖ до реберної дуги.

Такі обставини зумовлювали спрямованість сили скорочення ПМЖ у напрямки назовні. Міцність сітки та її фіксації повинні були забезпечити зведення ПМЖ до зменшення діастазу до відстані не більше 1 см та їх утримання в цьому положенні.

Особливістю фіксації сітки було ії пришивання до передньої поверхні апоневрозу ПМЖ у багатьох точках з проміжком між швами 1,5 - 2 см. Загальна кількість швів складала від 90 у хворих з апоневрозом більш високої щільності і міцності до 220 в разі витонченого прозорого апоневрозу, який більше походив на тонку фасцію, ніж на сухожилок. Завдяки використанню великої кількості швів досягали міцності фіксації, що дозволила в усіх спостереженнях усунути діастаз і закрити грижовий дефект.

Однак такий спосіб ліквідації грижі та діастазу мав два недоліки.

Суттєвим недоліком була відсутність можливості зведення внутрішніх країв ПМЖ при ширині грижових воріт більше 10 см.
У 3 пацієнтів виникла серома як реакція апоневрозу на сітку. Не зважаючи на багаторазові пункції, усунути серому вдалось лише шляхом висічення сітки.

Недоліки як першого, так і другого способів хірургічного втручання вдалось уникнути у 11 пацієнтів (3-тя група) з шириною діастазу 5 - 8 см та грижовими воротами M1 (1 спостереження), M2 (3), M4 (2), M2+M3+M4 (5), W1 (3), W2 (8), у яких метою операції була фіксація поліпропіленової сітки до відсепарованих задніх листків апоневрозу ПМЖ із подальшим їх зшиванням. Техніка втручання полягала в наступному.

Після здійснення серединного розрізу і грижорозтину відшаровували жирову клітковину й оголювали серединний апоневроз на ширину до 2 см від внутрішнього краю обох ПМЖ. Вздовж внутрішніх країв розсікали передній листок апоневрозу ПМЖ і піднімали м'язи (рис. 1). Розкривали задній листок апоневрозу по всій довжині та на всю ширину ПМЖ. Міжм'язові сухожильні перетинки піднімали разом із приєднаними до них сегментами м'язів, не порушуючи поздовжню цілісність ПМЖ. У всіх спостереженнях задній листок апоневрозу був дистрофічно змінений такою ж мірою, як і передній.

Поверх заднього листка апоневрозу з кожного боку окремими швами рядами по 5 швів з проміжками між ними 1,5 - 1,8 см та відстанню між рядами до 2,0 см пришивали поліпропіленові сітки розміром 6 х11 см (рис. 2). Відповідно до довжи-



Рис. 1. Розсікання переднього листка апоневрозу прямих м’язів живота і піднімання м’язів.

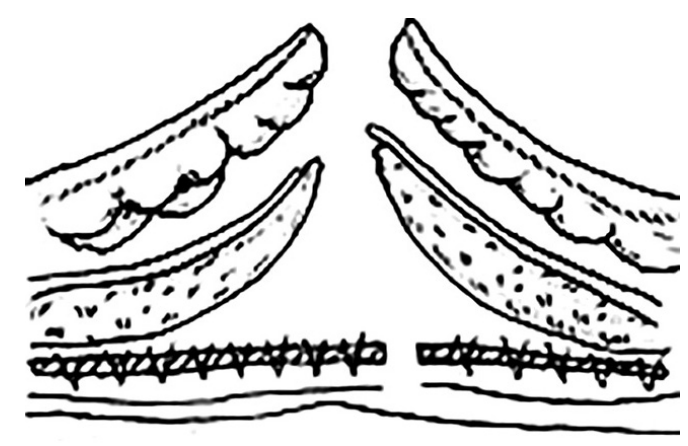

Рис. 2. Фіксування поліпропіленової сітки. 
ни ПМЖ використовували 3-5 сіток. Завдяки цьому задня стінка апоневрозу ставала міцнішою, достатньо для зближення впритул внутрішніх країв апоневрозу разом із сітками з обох сторін. Після зближення внутрішні краї апоневрозу разом з сітками зшивали окремими швами, створюючи суцільний задній листок апоневрозу ПМЖ (рис. 3). Внаслідок зшивання відстань між внутрішніми краями ПМЖ встановлювалась у межах 1,5 - 2 см.

Після цього можливо було зшити внутрішні краї передніх листків апоневрозу без натягу. Зашивали шкіру наглухо (рис. 4).

3 метою знеболення під час виконання операції за описаним способом застосовували комбінацію ендотрахеального наркозу та епідуральної анестезії на рівні Th9-Th10. Після операції впродовж 4-7 днів здійснювали епідуральну анестезію введенням 0,125 \% розчину бупівакаїну зі швидкістю 6 мл/год.

У всіх спостереженнях ендотрахеальний наркоз припинявся одночасно з закінченням операції, всі пацієнти самостійно переміщувались на каталку для перевезення в палату. Пацієнти починали вільно ходити на наступний день після операції.

Жоден з пацієнтів не скаржився на післяопераційний біль як причину обмеження рухів або поганого сну. Наркотичні препарати після операції не застосовували.

У ранньому післяопераційному періоді 3 пацієнти вказували на нечітко виражене відчуття не-

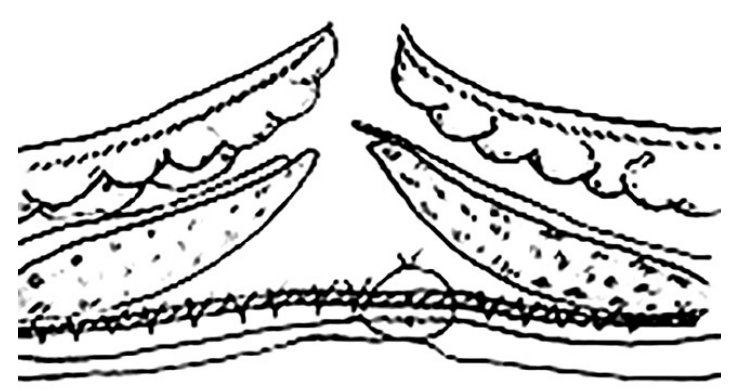

Рис. 3. Створення суцільного заднього листка апоневрозу прямих м’язів живота.

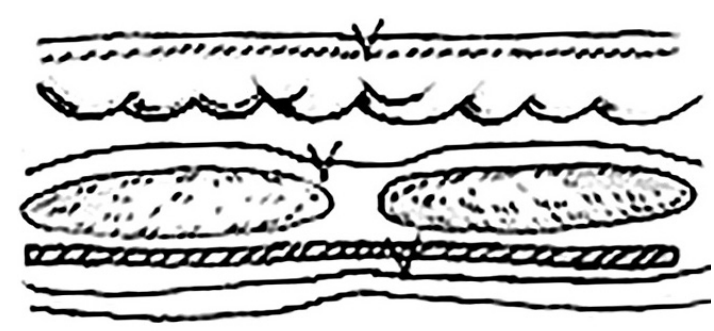

Рис. 4. Зшивання внутрішніх країв переднього листка апоневрозу. повноцінності вдиху. При цьому насичення гемоглобіну киснем становило $96-97$ \%. У жодному спостереженні не виникла потреба у застосуванні інгаляції кисню.

У термін до 6 тижнів після операції кожному пацієнту виконували 4 - 7 пункції сероми, яка накопичувалась у проміжку між переднім та заднім листками апоневрозів прямих м’язів живота. У всіх спостереженнях накопичення випоту в термін пізніше 6 тижнів після операції не спостерігали, нагноєння сероми або утворення кісти не було.

У термін 6-12 місяців після операції оглянуто 7 пацієнтів, через 3 - 5 років - 4. Рецидиву грижі, утворення інфільтрату або кісти на місці операційного рубця не спостерігали. Обмежень руху пацієнти не відмічали.

Існує розбіжність у ставленні до діастазу ПМЖ між косметичними та загальними хірургами.

Косметичні хірурги мають справу з діастазом ПМЖ, який виникає у жінок унаслідок розтягнення черевної стінки під час вагітності.

Так, при вимірюванні за допомогою ультразвукового дослідження у жінок через 3 тижні після пологів середня величина розходження ПМЖ становить 2,97 см із інтерквартильним розмахом 1,65 см [4].

Величина діастазу ПМЖ різниться при вимірюванні на різній висоті від пупка та нижче його: інтердецильний розмах між 20 та 80 \% величини діастазу ПМЖ у жінок під час першої вагітності становив 49 - 79 мм нижче пупка, 54 - 86 мм на 2 см вище пупка та 49 - 79 мм на 5 см вище пупка, через 6 місяців після пологів величини становили, відповідно, 9 - 21 мм, 17 - 28 мм та $12-$ 24 мм [5].

Зменшення відстані у віддалений термін після пологів свідчить про здатність серединного апоневрозу до скорочення. Величина діастазу збільшується пропорційно кількості пологів у жінки [6].

Хоча встановлено, що під час вправ, пов'язаних приведенням тулуба до колін, внутрішні краї ПМЖ зближуються [4], однак запобігання таким чином виникненню або усуненню їх діастазу не є достовірним [7].

На підставі системного огляду літератури вважають хірургічну корекцію діастазу ПМЖ косметичною процедурою, яка не завжди потребує хірургічного втручання [8], пов'язана з високою вірогідністю незадовільного результату та рецидиву розходження м’язів [9].

Наші дані не підтверджують такий підхід. Оскільки діастаз ПМЖ є наслідком широкого відстояння місць фіксації ПМЖ до реберної дуги, що ми спостерігали у всіх пацієнтів, ймовірність їх 


\section{З ДОСВІДУ РОБОТИ}

змикання відсутня через розходження при кожному скороченні м'язів. В разі виникнення грижі на тлі діастазу краї грижових воріт не мають схильності до зближення.

У хворих із великим обхватом талії сили, що розводять ПМЖ у різні напрямки, посилюються внаслідок їх розтягнення вперед і на бік.

Отже, в основі виникнення діастазу ПМЖ, ускладненого виникненням грижі, лежить особливість анатомічної будови черевної стінки, яка потребує спеціальної корекції.

Загальні хірурги вважають показанням до хірургічного втручання величину діастазу 3 см i більше, що викликає інші клінічні прояви [10]. 3 огляду на показання, результатом втручання має бути не стільки косметичний ефект, скільки усунення грижі та надійне зміцнення черевної стінки.

У проспективному рандомізованому дослідженні встановили, що загальна клінічна ефективність усунення діастазу ПМЖ більше 3 см із використанням позам'язового розміщення легкої поліпропіленової сітки або подвійного закриття передньої фасції живота за допомогою самозамикаючої технології Quill є однаковою, однак при оцінці ступеня корекції роботи м’язів застосування сітки виявилось більш дієвим [11].

Наші дані підтверджують важливість досягнення в результаті хірургічного втручання стану, коли обидва ПМЖ утворюють єдину суцільну конструкцію. Це може бути результатом зрощення ПМЖ із поліпропіленовою сіткою та зближення внутрішніх країв ПМЖ до відстані не більше 1 см.

Наявність діастазу ПМЖ більше 6 см або його поєднання 3 значною слабкістю апоневротичном’язових структур потребують застосування протезів для зміцнення черевної стінки [12].

У пацієнтів з надмірною масою тіла її зниження i, відповідно, зменшення обхвату талії малоймовірне. Навпаки, є високою вірогідність їх збільшення. За цих обставин застосування сітки, яка обмежує розтягнення стінки живота, відіграє роль “вартового”. Біль, що виникає при розтягненні живота через жорсткість сітки та ії фіксації, попереджає пацієнта про надмірне вживання їжі.

На відміну від трансректального пришивання сітки до задньої поверхні ПМЖ, яке застосовували [13], ми пришивали її окремими клаптями до виділеного заднього листка апоневрозу ПМЖ з кожного боку від серединної лінії. Мобільність виділеного окремо заднього листка апоневрозу вище, ніж ПМЖ, який знаходиться у власній піх- ві. Хоча в наших спостереженнях ширина грижових воріт, закритих у пацієнтів 3 групи, не перевищувала 10 см, однак, запас мобільності, який досягався під час операції, дозволяє припустити можливість закриття дефекту навіть при ширині грижових воріт до 12 см. Після зшивання в описаний спосіб задніх листків передні листки апоневрозу ПМЖ зближувались настільки, що ставало можливим їх зшивання край до краю без натягу. В разі грижі, що поширювалась нижче дугоподібної лінії, в нижніх відділах черевної стінки поліпропіленову сітку розміщували поверх преперитонеальної (поперечної) фасції, а її верхній край пришивали окремими швами до нижнього краю сіток, зшитих раніше. Нижній край сітки пришивали до задньої поверхні прямих м’язів, білої лінії та надлобкової фасції. Таким чином забезпечували правильне розміщення останньої сітки, запобігали її зсуванню та гофруванню. Пришивання сітки в запропонований спосіб дозволяло уникнути небезпек пошкодження епігастральних судин та міжм'язових нервів, притаманних накладенню швів через товщу м’яза.

Окрім того, використання в якості основи для закріплення сітки заднього листка апоневрозу робить непотрібним широке відкриття переднього листка апоневрозу, яке необхідне для здійснення трансректального проведення швів.

Застосована нами техніка здійснення реконструкції білої лінії живота шляхом окремого відновлення кожного з шарів забезпечує надійне відновлення їі міцності одночасно 3 збереженням функції кожного з них. Подібний підхід вважається найбільш ефективним для лікування великої післяопераційної грижі [13].

Висновки. 1. Оскільки в основі виникнення діастазу ПМЖ, ускладненого виникненням грижі, лежить особливість анатомічної будови черевної стінки, яка потребує спеціальної корекції, при його хірургічному лікуванні застосування сітки обов’язкове.

2. Мобілізація заднього листка апоневрозу ПМЖ і його зміцнення сіткою дозволяє закрити грижовий дефект завширшки до 12 см і є високоефективним методом лікуванням грижі на тлі діастазу ПМЖ.

3. Застосування комбінації ендотрахеального наркозу та епідуральної анестезії з продовженням епідуральної анестезії впродовж 4- 7 днів після операції забезпечує безбольовий перебіг післяопераційного періоду. 


\section{З ДОСВІДУ РОБОТИ}

\section{СПИСОК ЛІТЕРАТУРИ}

1. Relationship between diastasis of the rectus abdominis muscle (DRAM) and musculoskeletal dysfunctions, pain and quality of life: a systematic review / D. R. Benjamin, H. C. Frawley, N. Shields [et al.] // Physiotherapy. - 2019. - Vol. 105. - Issue 1. - P. 24-34.

2. Köhler G. Sutured repair of primary small umbilical and epigastric hernias: concomitant rectus diastasis is a significant risk factor for recurrence / G. Köhler, R. R. Luketina, K. Emmanuel // World J. Surg. - 2015. - Vol. 39 (1). - P. 121-126.

3. Ventral Hernia Working Group. Incisional ventral hernias: review of the literature and recommendations regarding the grading and technique of repair / K. Breuing, C. E. Butler, S. Ferzoco [et al.] // Surgery. - 2010. - Vol. 148 (3). - P. 544-558. 4. Abdominal exercises affect inter-rectus distance in postpartum women: a two-dimensional ultrasound study / M. F. Sancho, A. G. Pascoal, P. Mota, K. Bø // Physiotherapy. - 2015. - Vol. 101. - Issue 3. - P. 286-291.

5. Normal width of the inter-recti distance in pregnant and postpartum primiparous women / P. Mota, A. G. Pascoal, A. I. Carita, K. Bø // Musculoskelet Sci. Pract. - 2018. - Vol. 35. - P. 34.

6. Prevalence of diastasis recti abdominis in the population of young multiparous adults in Turkey / V. Turan, C. Colluoglu, E. Turkyilmaz, U. Korucuoglu // Ginekol. Pol. - 2011. - Vol. 82 (11). - P. 817.

7. Benjamin D. R. Effects of exercise on diastasis of the rectus abdominis muscle in the antenatal and postnatal periods: a

\section{REFERENCES}

1. Benjamin, D.R., Frawley H.C., Shields, N., van de Water, A.T.M., \& Taylor N.F. (2019). Relationship between diastasis of the rectus abdominis muscle (DRAM) and musculoskeletal dysfunctions, pain and quality of life: a systematic review. Physiotherapy, 105 (1), 2434. Retrieved from: https://doi.org/10.1016/j.physio.2018.07.002 2. Köhler, G., Luketina, R.R., \& Emmanuel, K. (2015). Sutured repair of primary small umbilical and epigastric hernias: concomitant rectus diastasis is a significant risk factor for recurrence. World $J$. Surg., 39 (1), 121-126. doi: 10.1007/s00268-014-2765-y.

3. Ventral Hernia Working Group, Breuing, K., Butler, C.E., Ferzoco, S., Franz, M., Hultman, C.S., ..., \& Vargo, D. (2010). Incisional ventral hernias: review of the literature and recommendations regarding the grading and technique of repair. Surgery, 148 (3), 544-558. doi: 10.1016/j.surg.2010.01.008.

4. Sancho, M.F., Pascoal, A.G., Mota, P., \& Bø, K. (2015). Abdominal exercises affect inter-rectus distance in postpartum women: a two-dimensional ultrasound study. Physiotherapy, 101 (3), 286-291. Retrieved from: https://doi.org/10.1016/j. physio.2015.04.004

5. Mota, P., Pascoal, A.G., Carita, A.I., \& Bø, K. (2018). Normal width of the inter-recti distance in pregnant and postpartum primiparous women. Musculoskelet Sci. Pract., 35, 34.

6. Turan, V., Colluoglu, C., Turkyilmaz, E., \& Korucuoglu, U. (2011). Prevalence of diastasis recti abdominis in the population of young multiparous adults in Turkey. Ginekol. Pol., 82 (11), 817. 7. Benjamin, D.R., van de Water, A.T.M., \& Peiris, C.L. (2014). Effects of exercise on diastasis of the rectus abdominis systematic review / D. R. Benjamin, A. T. M. van de Water, C. L. Peiris // Physiotherapy. - 2014. - Vol. 100. - Issue 1. - P. 1-8. 8. Akram J. Rectus abdominis diastasis / J. Akram, S. H. Matzen // J. Plast. Surg. Hand Surg. - 2014. - Vol. 48 (3). - P. 163-169. 9. Hickey F. A systematic review on the outcomes of correction of diastasis of the recti / F. Hickey, J. G. Finch, A. Khanna // Hernia. - 2011. - Vol. 15 (6). - P. 607-614.

10. Early complications, pain, and quality of life after reconstructive surgery for abdominal rectus muscle diastasis: a 3-month follow-up / P. Emanuelsson, U. Gunnarsson, K. Strigård, B. Stark // J. Plast. Reconstr. Aesthet. Surg. - 2014. - Vol. 67 (8). - P. 1082-1088.

11. Totally endoscopic surgery on diastasis recti associated with midline hernias. The advantages of a minimally invasive approach. Prospective cohort study / J. Bellido Luque, A. Bellido Luque, J. Valdivia [et al.] // Hernia. - 2015. - Vol. 19 (3). P. 493-501.

12. Cheesborough J. E. Simultaneous prosthetic mesh abdominal wall reconstruction with abdominoplasty for ventral hernia and severe rectus diastasis repairs / J. E. Cheesborough, G. A. Dumanian // Plast. Reconstr. Surg. - 2015. - Vol. 135 (1). - P. 268-276.

13. Chandeze M. M. Large incisional hernias: The double layer technique with anterior component separation (with video) / M. M. Chandeze, D. Moszkowicz, J. L. Bouillot // J. Visc. Surg. - 2019. - pii: S1878-7886(19)30094-3.

muscle in the antenatal and postnatal periods: a systematic review. Physiotherapy, 100 (1), 1-8. Retrieved from: https://doi. org/10.1016/j.physio.2013.08.005.

8. Akram, J., \& Matzen, S.H. (2014). Rectus abdominis diastasis. J. Plast. Surg. Hand Surg., 48 (3), 163-169. doi:10.3109/200065 6X.2013.859145.

9. Hickey, F., Finch, J.G., \& Khanna, A. (2011). A systematic review on the outcomes of correction of diastasis of the recti. Hernia, 15 (6), 607-614.

10. Emanuelsson, P., Gunnarsson, U., Strigård, K., \& Stark, B. (2014). Early complications, pain, and quality of life after reconstructive surgery for abdominal rectus muscle diastasis: a 3-month followup. J. Plast. Reconstr. Aesthet. Surg., 67 (8), 1082-1088.

11. Bellido Luque, J., Bellido Luque, A., Valdivia, J., Suarez Gráu, J.M., Gomez Menchero, J., García Moreno, J., \& Guadalajara Jurado, J. (2015). Totally endoscopic surgery on diastasis recti associated with midline hernias. The advantages of a minimally invasive approach. Prospective cohort study. Hernia, 19 (3), 493-501. doi:10.1007/s10029-014-1300-2.

12. Cheesborough, J.E., \& Dumanian, G.A. (2015). Simultaneous prosthetic mesh abdominal wall reconstruction with abdominoplasty for ventral hernia and severe rectus diastasis repairs. Plast. Reconstr. Surg., 135 (1), 268-276.

13. Chandeze, M.M., Moszkowicz, D., \& Bouillot, J.L. (2019). Large incisional hernias: The double layer technique with anterior component separation (with video). J. Visc. Surg. pii: S18787886(19)30094-3. doi: 10.1016/j.jviscsurg.2019.06.014. 


\title{
S. E. PODPRYATOV, I. O. BELOUSOV, S. S. PODPRIATOV, V. V. IVAHA, V. P. KORCHAK
}

Kyiv Municipal Hospital No. 1

\section{SURGICAL TREATMENT OF DIASTASIS RECTUS ABDOMINIS AND HERNIAS ON ITS BACKGROUND}

The aim of the work: to assess the effectiveness of different techniques of rectus abdominis (RA) diastasis (D) surgical correction as to the point of aim attainment and patient's satisfaction.

Materials and Methods. 92 patients were operated on, 49 men and 43 women at the age from 40 to 72 years with body mass index from 27.2 to $48.6 \mathrm{~kg} / \mathrm{cm}^{2}$.

Incisional hernia has 47 patients, umbilical or supraumbilical - 45 .

Hernia M1 has 1 patient, M2 - 11, M3 - 42, M4 - 8, M2+M3+M4 - 30, W1 3, W2 - 48, W3 - 41.

Results and Discussion. Ramirez O.M. et al., 1990, technique with mesh placement was used for hernia closure and D liquidation in 5 cases. Even as the surgery aim had been achieved in all cases, in follow up RA fully and lateral abdominal muscles nearly fully lost their ability to contract which caused considerable restriction of patients' trunk movement.

76 patients were treated by anterior aponeurotic sheet armoring by mesh on lay placement and nearing RA edges by this mean. Live tissue welding technique by means EK-300M1 and Patonmed EKVZ 300 apparats was used for tissue mobilization. D width in epigastrium reflected the distance between the points of RA fixation at the costal arc. Seroma occur in 3 cases leading to mesh removing. Also it was impossible to draw close RA in the case of herniation foramen more $10 \mathrm{~cm}$ in width. Posterior sheets of RA mobilization with its armoring by mesh and further suturing was used in 11 patients with full success. RA D is the result of wide situation their places of fixation to the costal arc which was founded in all cases, thereafter their joining is impossible due to divergence in every muscle's contraction. In the case of coincidence of D RA and herniation hernia gape have no tendency to closing. Posterior sheets of RA mobilization with its armoring by mesh and further suturing mesh use allow to close hernia defect up to $12 \mathrm{~cm}$ in width and seem to be highly effective in case of hernia with the RA D background.

Combined use of endotracheal narcosis and epidural anesthesia with a prolonged epidural anesthesia throughout 4-7 days after surgery ensure painless postoperative period.

Key words: recti abdominis muscle diastasis; hernia; surgical treatment.

\author{
С. Е. ПОДПРЯТОВ, И. О. БЕЛОУСОВ, С. С. ПОДПРЯТОВ, В. В. ИВАХА, В. П. КОРЧАК
}

Киевская городская клиническая больница № 1

\section{ХИРУРГИЧЕСКОЕ ЛЕЧЕНИЕ ДИАСТАЗА ПРЯМЫХ МЫШШ ЖИВОТА И ГРЫЖ НА ЕГО ФОНЕ}

Цель работы: оценить эффективность различных способов хирургического лечения диастаза прямых мышц живота (ПМЖ) с позиций достижения цели оперативного вмешательства и приемлемости для пациента.

Материалы и методы. Хирургическое вмешательство проведено 92 пациентам: 49 мужчинам и 43 женщинам в возрасте от 40 до 72 лет. Индекс массы тела у пациентов составлял от 27,2 до 48,6 кг/см².

У 47 пациентов на фоне диастаза ПМЖ возникла послеоперационная грыжа, у 45 - первичная. Грыжа М - у 1 пациента, М2 - у 11, M3 - y 42, M4 - y 8, M2+M3+M4 - y 30, W1 - y 3, W2 - y 48, W3 - y 41.

Результаты исследований и их обсуждение. У 5 пациентов устранение грыжи и диастаз ПМЖ и закрытие грыжевых ворот осуществили по способу Ramirez O. M. et al., 1990, дополненным размещением полипропиленовой сетки позади ПМЖ. Хотя цель операции была достигнута во всех наблюдениях, однако в послеоперационном периоде ПМЖ полностью, а боковые мышцы в значительной мере утратили способность сокращаться, что существенно ограничило движения туловища пациентов. В 76 наблюдениях применили укрепление переднего листка апоневроза с помощью размещения сетки оn lay и сближения с ее помощью ПМЖ. Мобилизацию осуществляли с помощью технологии электросварки живых тканей и аппаратов ЕК 300-M1 и Патонмед ЕКВ3 300. Во всех наблюдениях ширина диастаза отражала расстояние между точками фиксации внутренних краев ПМЖ к реберной дуге. Оказалось невозможным сведение внутренних краев ПМЖ при ширине грыжевых ворот больше 10 см. У 3 пациентов возникла серома, что потребовало удаления сетки. У 11 пациентов с успехом была осуществлена фиксация сетки к мобилизованным задним листкам апоневроза ПМЖ с их дальнейшим сшиванием. Возникновение диастаза ПМЖ является следствием широкого отстояния мест фиксации ПМЖ к реберной дуге, что мы отметили во всех наблюдениях, вероятность их смыкания отсутствует по причине расхождения при каждом сокращении мышц. В случае возникновения грыжи на фоне диастаза края грыжевых ворот не имеют тенденции к сближению. Мобилизация заднего листка апоневроза ПМЖ и его укрепление сеткой позволяет закрыть грыжевой дефект шириной до 12 см и является высокоэффективным при лечении грыжи на фоне диастаза ПМЖ.

Применение эндотрахеального наркоза и эпидуральной анестезии с продолжением эпидуральной анестезии в течение 4-7 дней после операции обеспечивает безболевое течение послеоперационного периода.

Ключевые слова: диастаз прямых мышц живота; грыжа; хирургическое лечение. 